\title{
Multivalent display of the antimicrobial peptides BP100 and BP143
}

\author{
Imma Güell ${ }^{1, \S}$, Rafael Ferre ${ }^{1, \S}$, Kasper K. Sørensen ${ }^{2, \S}$, Esther Badosa ${ }^{3}$, \\ Iteng Ng-Choi ${ }^{1}$, Emilio Montesinos ${ }^{3}$, Eduard Bardaji ${ }^{1}$, Lidia Feliu ${ }^{1}$, \\ Knud J. Jensen ${ }^{* 2}$ and Marta Planas ${ }^{* 1}$
}

\section{Full Research Paper}

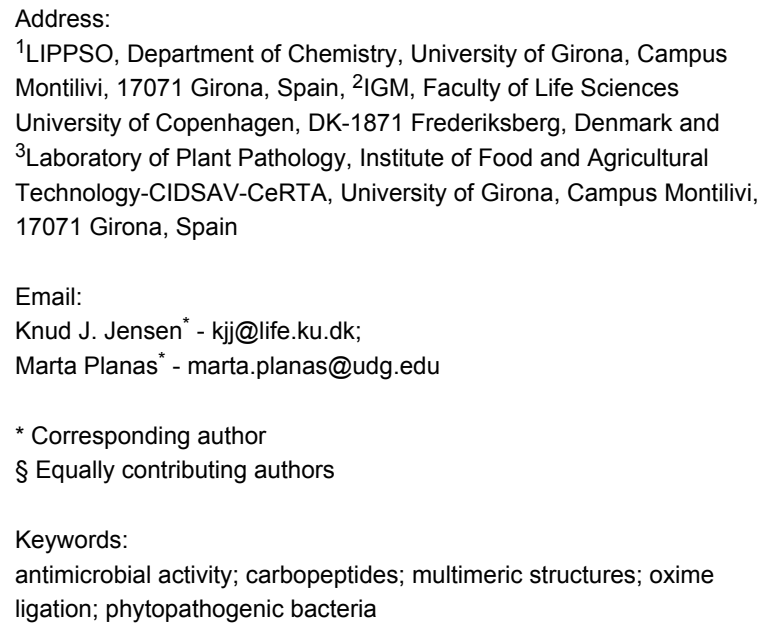

Beilstein J. Org. Chem. 2012, 8, 2106-2117. doi:10.3762/bjoc.8.237

Received: 27 July 2012

Accepted: 07 November 2012

Published: 03 December 2012

Associate Editor: K. N. Ganesh

(C) 2012 Güell et al; licensee Beilstein-Institut. License and terms: see end of document.

\footnotetext{
Abstract

Carbohydrates are considered as promising templates for the display of multiple copies of antimicrobial peptides. Herein, we describe the design and synthesis of chimeric structures containing two or four copies of the antimicrobial peptides KKLFKKILKYL-NH ${ }_{2}$ (BP100) and KKLfKKILKYL-NH 2 (BP143) attached to the carbohydrate template cyclodithioerythritol (cDTE) or $\alpha$-D-galactopyranoside (Gal $p$ ). The synthesis involved the preparation of the corresponding peptide aldehyde followed by coupling to an aminooxy-functionalized carbohydrate template. After purification, the multivalent display systems were obtained in high purities (90-98\%) and in good yields (42-64\%). These compounds were tested against plant and human pathogenic bacteria and screened for their cytotoxicity on eukaryotic cells. They showed lower MIC values than the parent peptides against the bacteria analyzed. In particular, the carbopeptides derived from cDTE and Gal $p$, which contained two or four copies of BP100, respectively, were 2- to 8 -fold more active than the monomeric peptide against the phytopathogenic bacteria. These results suggest that preassembling antimicrobial peptides to multimeric structures is not always associated with a significant improvement of the activity. In contrast, the carbopeptides synthesized were active against human red blood cells pointing out that peptide preassembly is critical for the hemolytic activity. Notably, peptide preassembly resulted in an enhanced bactericidal effect.
} 


\section{Introduction}

The emergence of antibiotic resistance is a major problem in human health as well as in agronomy and there is a considerable current interest in developing novel antimicrobial compounds $[1,2]$. In recent years, a growing number of studies have shown that antimicrobial peptides constitute a potential alternative to traditional antibiotics. To date, a very large number of antimicrobial peptides have been produced based on naturally occurring products or by de novo design, and most of them display a broad spectrum of antimicrobial activities [3,4] Despite their remarkable structural diversity, these peptides share several characteristics: the sequence length is typically between 12 to 59 amino acids, they bear a positive charge of +2 to +9 , and they show an amphipathic character. The electrostatic interaction of antimicrobial peptides with membranes is a key factor in determining their biological activity [1,3,5-8]. For many of these peptides, membrane disruption is considered the primary mechanism of cell death. Although a general understanding has been achieved, the precise mechanism of peptide-membrane interaction and cell killing has not been firmly established for many peptides. Several models have been proposed to account for the morphologic changes in the membrane induced by antimicrobial peptides, such as pore formation, lysis or peptide translocation into the cytoplasm. Either model relies on relatively high local density and synergy of monomeric peptides.

It has occasionally been reported that an improved binding to microbial membranes and thus an improved antimicrobial activity can be achieved if several copies of an antimicrobial peptide are linked together to form multimeric species [9-15]. The hypothesis of the assembly model is based on prenucleating a number of appropriately spaced and oriented antimicrobial peptide monomers in order to reduce the threshold concentration required for their activity. The interaction of these multivalent species should a priori make the interaction with the microbial membrane strongly and entropically more favorable. Representative studies include multimeric derivatives of alamethicin [16] and the dimeric antimicrobial peptide A3-APO [17]. Moreover, studies of multivalent antimicrobial peptides are of growing importance because they could represent an interesting tool to provide insights into the modes of action of antimicrobial peptides, which are generally poorly understood.

Several scaffolds, such as linear and cyclic peptides, alkynefunctionalized dendrimers, a branched lysine core, and also a polymaleic polymer, have been exploited as templates for the synthesis of multivalent antimicrobial peptides [18-22]. Carbohydrates are promising candidates as templates for the display of functional groups due to their inherent multifunctionality, the relative rigidity of their structure, and the ease of regioselective chemical manipulation [23-25]. Jensen and co-workers reported the synthesis of carbopeptides and carboproteins bearing several copies of a peptide or a protein tethered in a carbohydrate template. They developed an efficient strategy for the synthesis of these carboproteins, in which C-terminal peptide aldehydes are ligated by oxime bond formation to aminooxyacetyl-functionalized monosaccharide templates, such as cyclodithioerythritol (cDTE) or $\alpha$-D-galactopyranoside (Galp) [23,26,27].

Here we describe the use of carbohydrate templates for the display of multiple copies of antimicrobial peptides. Our aim in this study was to evaluate whether the assembly of cecropin A-melittin antimicrobial undecapeptide hybrids on a carbohydrate template could provide carbopeptides with improved biological properties. In particular, KKLFKKILKYL-NH 2 (BP100) and KKLfKKILKYL-NH 2 (BP143) were selected based on their high antibacterial activity against the plant pathogenic bacteria Erwinia amylovora, Xanthomonas axonopodis pv. vesicatoria and Pseudomonas syringae pv. syringae [28,29]. BP100 displayed minimum inhibitory concentration (MIC) values in the range $2.5-7.5 \mu \mathrm{M}$ and also showed low hemolysis $(22 \%$ at $150 \mu \mathrm{M})$. BP143, which contains one D-amino acid, was as active, significantly less hemolytic $(2 \%$ at $150 \mu \mathrm{M})$, and more stable to protease degradation than BP100. Thus, carbopeptides 1-3 were designed and synthesized by linking two or four copies of BP100 and BP143 on a cDTE or a Galp template (Figure 1). The antibacterial and hemolytic activities and the bactericidal effect of the carbopeptides 1-3 were analyzed and will be discussed.

\section{Results \\ Design and synthesis of the carbopeptides}

Two-stranded and four-stranded carbopeptides 1-3 were designed by coupling of two or four copies of a C-terminal undecapeptide aldehyde to an aminooxy-functionalized carbohydrate template (Figure 1). The previously reported cyclodithioerythritol (cDTE) was used as a template for the two-stranded carbopeptides 1 and 2 [23,26,27]. The $\alpha$-Dgalactopyranoside ( $\mathrm{Gal} p$ ) template was required to obtain the four-stranded carbopeptide 3 . The sequence of the peptide aldehydes was based on the peptides KKLFKKILKYL-NH (BP100) and KKLfKKILKYL-NH 2 (BP143), which have been shown to display high antibacterial activity $[28,29]$.

Templates cDTE and Gal $p$ functionalized with aminooxyacetic acid were prepared as before $[23,30]$. Peptide aldehydes KKLFKKILKYLG-H (4) and KKLfKKILKYLG-H (5), derived from BP100 and BP143, respectively, were prepared by using a standard backbone amide linker (BAL) strategy (Scheme 1). PALdehyde was coupled onto an amino-functionalized 


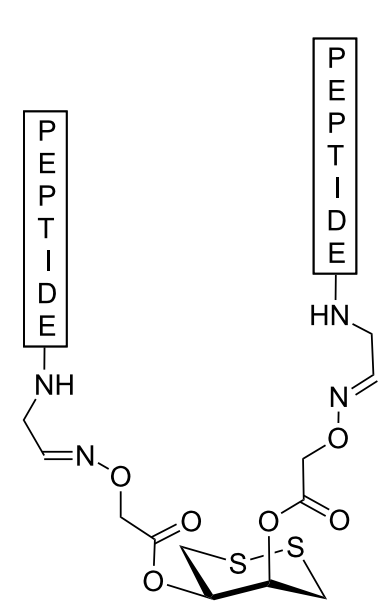

Carbopeptide

1 (KKLFKKILKYL- $\left.{ }_{2} \mathrm{H}_{4} \mathrm{~N}\right)_{2}$-CDTE $2\left(\text { KKLfKKILKYL- }{ }_{2} \mathrm{H}_{4} \mathrm{~N}\right)_{2}$-CDTE

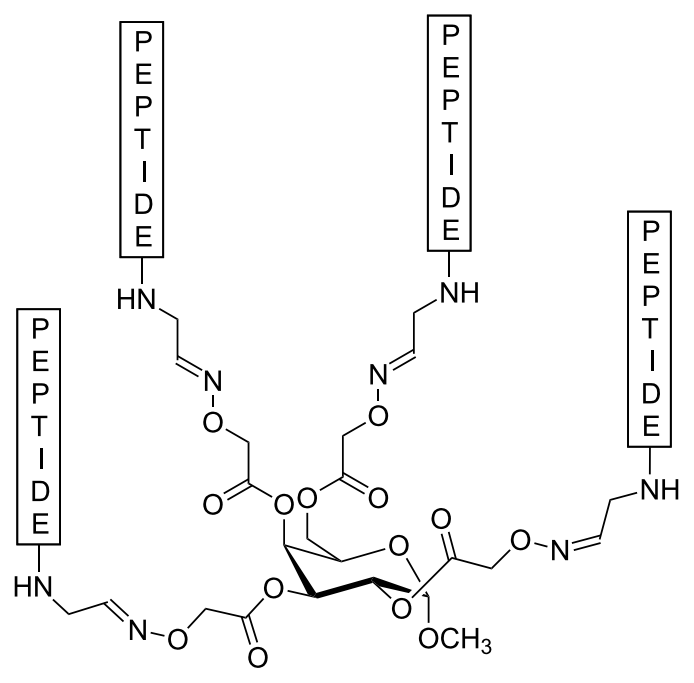

Carbopeptide

$3\left(\text { KKLFKKILKYL- }{ }_{2} \mathrm{H}_{4} \mathrm{~N}\right)_{4}$-Galp

Figure 1: Structure of the carbopeptides 1-3.

TentaGel (TG) resin followed by reductive amination with aminoacetaldehyde dimethyl acetal, which served as a precursor for the C-terminal glycinal residue. Next, acylation of the secondary nitrogen with Fmoc-Leu-OH was mediated by $N, N^{\prime}$-di- isopropylcarbodiimide (DIPCDI) with microwave heating at $60{ }^{\circ} \mathrm{C}$. Peptide chain elongation followed standard 9-fluorenylmethoxycarbonyl (Fmoc) solid-phase chemistry. After chain assembly was completed, peptides were released from the<smiles>[CH]NC(=O)CCCCOc1cc(OC)cc(OC)c1C=O</smiles><smiles>COCC(CN)OC</smiles>

$\mathrm{NaBH}_{3} \mathrm{CN}, \mathrm{AcOH} / \mathrm{DMF}$ $60{ }^{\circ} \mathrm{C}, \mathrm{MW}$<smiles>[CH]NC(=O)CCCCOc1cc(OC)cc(OC)c1CN(CC(OC)OC)C(F)(F)Cl</smiles><smiles>COCCCC1CC1CN(Cc1c(OC)cc(OC)cc1OC)CC(OC)OC</smiles><smiles>[CH]NC(=O)CCCCOc1cc(OC)cc(OC)c1CNCC(OC)OC</smiles>

\section{Peptide chain elongation}

Fmoc removal: piperidine/DMF couplings: Fmoc-Aa-OH, HBTU, HOBt, DIPEA, DMF or NMP 
support by treatment with trifluoroacetic acid (TFA), which removed the tert-butyl ( $t$-Bu)/tert-butyloxycarbonyl (Boc) groups and also hydrolyzed the acetal to the required aldehyde. When the cleavage was performed by using TFA/triisopropylsilane (TIS) $/ \mathrm{H}_{2} \mathrm{O}$ (95:2.5:2.5), the corresponding peptide alcohol was obtained. It has been previously reported that silanes under acidic conditions can promote the reduction of aldehydes [27] Cleavage of the peptidyl resins with TFA/ $\mathrm{H}_{2} \mathrm{O}$ (95:5) followed by purification by reversed-phase high-performance liquid chromatography (RP-HPLC) afforded peptide aldehydes $\mathbf{4}$ and $\mathbf{5}$ in $99 \%$ purity, and their structure was confirmed by electrosprayionization mass spectrometry (ESIMS).
With templates and peptide aldehydes in hand, the fourstranded structure 3 was prepared from Gal $p$ and peptide aldehyde 4 (Scheme 2). First, the reaction was conducted in a 1:1 solution of $\mathrm{CH}_{3} \mathrm{CN}$ and acetate buffer $(0.1 \mathrm{M}, \mathrm{pH} 4.76)$ at room temperature for $2 \mathrm{~h}$, but the expected carbopeptide 3 was not obtained. Since the use of aniline as nucleophilic catalyst for oxime ligation has been described to enhance reaction rates by up to three orders of magnitude [31-33], we assayed the formation of 3 using the previous $\mathrm{CH}_{3} \mathrm{CN} /$ acetate buffer solution but containing aniline $(100 \mathrm{mM})$. Under these conditions we could not detect the carbopeptide 3 even when increasing the reaction time up to $48 \mathrm{~h}$. Results were improved by lyophilizing the
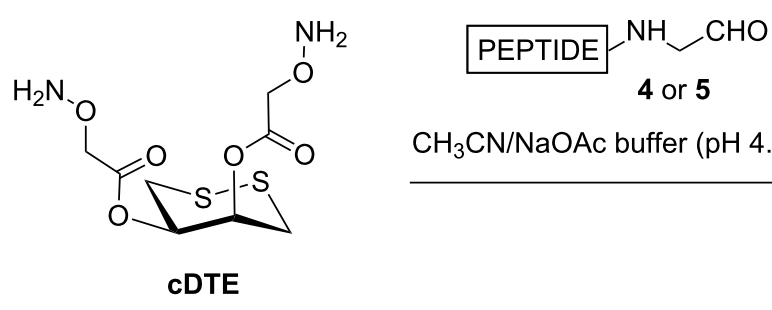

$\mathrm{CH}_{3} \mathrm{CN} / \mathrm{NaOAc}$ buffer ( $\left.\mathrm{pH} 4.76\right)$
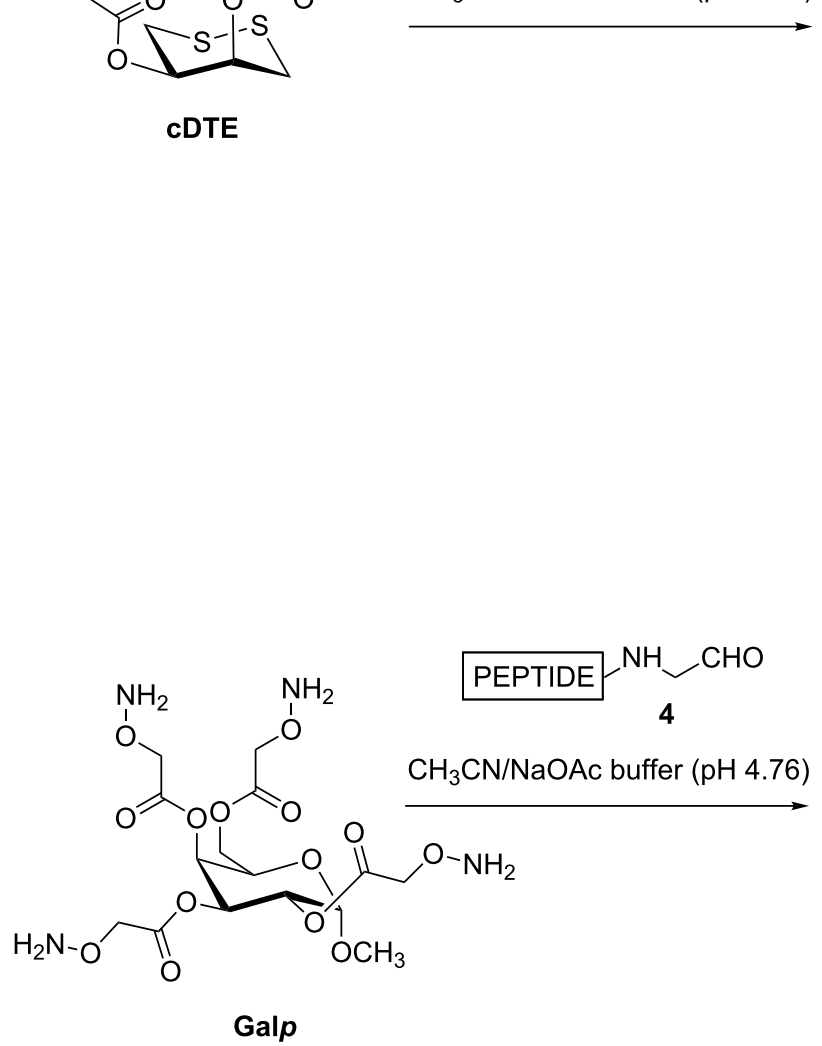

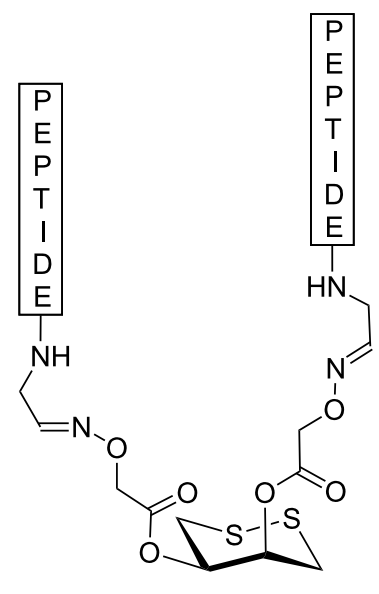

\section{Carbopeptide}

1 (KKLFKKILKYL- $\left.\mathrm{C}_{2} \mathrm{H}_{4} \mathrm{~N}\right)_{2}$-CDTE

$2\left(\text { KKLfKKILKYL- } \mathrm{C}_{2} \mathrm{H}_{4} \mathrm{~N}\right)_{2}$-CDTE

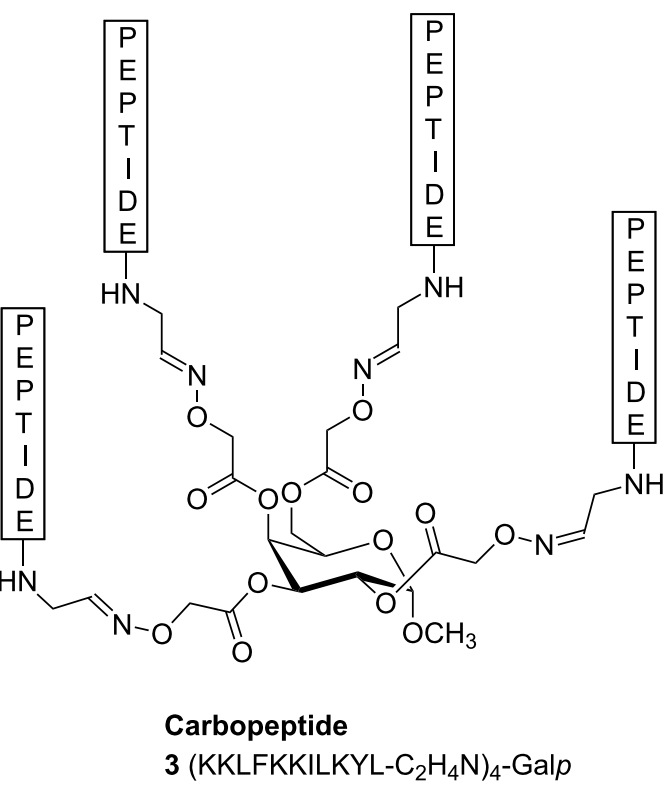


template prior to the oxime ligation. In this case, the reaction afforded 3 with or without the presence of aniline in the solvent mixture. Best conditions involved the treatment of lyophilized Gal $p$ with peptide aldehyde 4 in $(1: 1) \mathrm{CH}_{3} \mathrm{CN} /$ acetate buffer for $4 \mathrm{~h}$, followed by the addition of an extra amount of $\mathbf{4}$ dissolved in (1:1) $\mathrm{CH}_{3} \mathrm{CN} /$ acetate buffer containing aniline (100 mM). The reaction was completed after $2.5 \mathrm{~h}$ affording 3 , which was purified by RP-HPLC (90\% purity, 64\% yield) and characterized by mass spectrometry.

The synthesis of carbopeptide $\mathbf{1}$ was achieved by oxime ligation of cDTE, previously lyophilized, with peptide aldehyde 4 in a 1:1 solution of $\mathrm{CH}_{3} \mathrm{CN}$ and acetate buffer $(0.1 \mathrm{M}, \mathrm{pH} 4.76)$ containing aniline $(100 \mathrm{mM})$ at room temperature for $3 \mathrm{~h}$. The crude mixture was purified yielding 1 in $98 \%$ purity and $42 \%$ yield. This methodology was extended to the preparation of carbopeptide $\mathbf{2}$ derived from peptide aldehyde $\mathbf{5}$ with one D-amino acid in the sequence. The reaction was followed by HPLC being completed after $3 \mathrm{~h}$. After purification, carbopeptide 2 was obtained in $98 \%$ purity and $62 \%$ yield. The structure of carbopeptides $\mathbf{1}$ and $\mathbf{2}$ was confirmed by mass spectrometry.

\section{Biological activity}

Carbopeptides 1-3 were tested for in vitro growth inhibition of phytopathogenic bacteria Erwinia amylovora, Xanthomonas axonopodis pv. vesicatoria, and Pseudomonas syringae pv. syringae, and of human pathogenic bacteria Escherichia coli, Staphylococcus aureus, Lysteria monocytogenes, and Salmonella enterica at $0.6,1.2,2.5,5,7.5,10$ and $20 \mu \mathrm{M}$ (Table 1). The antibacterial activity of BP100 and BP143 was also evaluated for comparison purposes.

Against phytopathogenic bacteria, carbopeptides $\mathbf{1}$ and $\mathbf{3}$ displayed higher activity than the parent peptide BP100. Carbopeptide 3, derived from Gal $p$, was the most active with minimum inhibitory concentration (MIC) values from four- to eight-fold lower (MIC of 0.6 to $2.5 \mu \mathrm{M}$ ) than those of BP100
(MIC of 5 to $10 \mu \mathrm{M}$ ). The cDTE-containing carbopeptide 1 was two- to eight-fold (MIC of 0.6 to $5 \mu \mathrm{M}$ ) more active than BP100. In contrast, carbopeptide 2 derived from cDTE and BP143 showed similar activity to the parent peptide (MIC of 2.5 to $5 \mu \mathrm{M}$ ). Against the human pathogenic bacteria, the three carbopeptides 1-3 showed higher activity than the corresponding parent peptide, with E. coli and S. enterica being the most sensitive pathogens (MIC of 1.2 to $5 \mu \mathrm{M}$ ).

The toxicity of carbopeptides 1-3 to eukaryotic cells was also evaluated and it was determined as the ability to lyse erythrocytes in comparison to melittin. Percent hemolysis at 50 and $150 \mu \mathrm{M}$ is included in Table 1. Results showed that the parent peptides BP100 and BP143 were not hemolytic at these concentrations. In contrast, carbopeptides 1-3 were able to lyse erythrocytes at both concentrations suggesting that peptide preassembly is critical for the hemolytic activity.

Moreover, we analyzed the bactericidal effect of carbopeptides 1-3 against $E$. amylovora and $S$. enterica by comparing the time course to kill suspensions of mid-logarithmic-phase cultures of these bacterial strains. As shown in Figure 2, the monomeric peptides BP100 and BP143 showed a bactericidal effect against both strains, but it was slower against $S$. enterica. Both peptides exhibited an initial fast killing stage of 30-60 min, followed by a slower rate against E. amylovora. Notably, carbopeptides 1-3 were significantly more active against both pathogens and were able to kill $99.99 \%$ of all cells within $30-90 \mathrm{~min}$ at $2.5 \mu \mathrm{M}$.

\section{Circular dichroism}

We investigated the secondary structures of carbopeptides $\mathbf{1}$ and 3 by analyzing their CD spectra at $100 \mu \mathrm{M}$ in (i) $10 \mathrm{mM}$ sodium phosphate buffer at $\mathrm{pH} 7.4$; (ii) $50 \%(\mathrm{v} / \mathrm{v})$ trifluoroethanol (TFE) in $10 \mathrm{mM}$ sodium phosphate buffer at $\mathrm{pH}$ 7.4; and (iii) $10 \mathrm{mM}$ SDS in $10 \mathrm{mM}$ sodium phosphate buffer at $\mathrm{pH} 7.4$ (Figure 3). Carbopeptides $\mathbf{1}$ and $\mathbf{3}$ had similar CD spectra. In phosphate buffer they displayed a disordered structure while in

Table 1: Antibacterial activity (MIC) and cytotoxicity of parent peptides and carbopeptides.

\begin{tabular}{|c|c|c|c|c|c|c|c|c|c|}
\hline \multirow{2}{*}{ Compound } & \multicolumn{7}{|c|}{$\operatorname{MIC}(\mu \mathrm{M})$} & \multicolumn{2}{|c|}{ Hemolysis $^{a}(\%)$} \\
\hline & $E a^{b}$ & $X a v^{b}$ & $P s s^{b}$ & $E c^{b}$ & $S a^{b}$ & $L m^{\mathrm{b}}$ & $S e^{b}$ & $50 \mu \mathrm{M}$ & $150 \mu \mathrm{M}$ \\
\hline KKLFKKILKYL-NH 2 (BP100) & $7.5-10$ & $5-7.5$ & $5-7.5$ & $2.5-5$ & $>20$ & $>10$ & $5-10$ & $3 \pm 0.1$ & $22 \pm 2.8$ \\
\hline KKLfKKILKYL-NH2 2 (BP143) & $2.5-5$ & $5-7.5$ & $2.5-5$ & $10-20$ & $>20$ & $>20$ & $5-7.5$ & $2 \pm 2.8$ & $22 \pm 2.6$ \\
\hline$\left(\mathrm{KKLFKKILKYL-} \mathrm{C}_{2} \mathrm{H}_{4} \mathrm{~N}\right)_{2}$-CDTE (1) & $2.5-5$ & $0.6-1.2$ & $1.2-2.5$ & $2.5-5$ & $10-20$ & $5-7.5$ & $2.5-5$ & $100 \pm 4.1$ & $99 \pm 5.2$ \\
\hline$\left(\mathrm{KKLfKKILKYL-}{ }_{2} \mathrm{H}_{4} \mathrm{~N}\right)_{2}$-cDTE (2) & $2.5-5$ & $2.5-5$ & $2.5-5$ & $1.2-2.5$ & $10-20$ & $7.5-10$ & $2.5-5$ & $96 \pm 0.9$ & $92 \pm 7.2$ \\
\hline 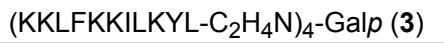 & $1.2-2.5$ & $0.6-1.2$ & $0.6-1.2$ & $1.2-2.5$ & $>20$ & $5-7.5$ & $2.5-5$ & $100 \pm 18.8$ & $100 \pm 1.1$ \\
\hline
\end{tabular}

aPercentage hemolysis plus confidence interval. ${ }^{b}$ Ea, Erwinia amylovora; Xav, Xanthomonas axonopodis pv. vesicatoria; Pss, Pseudomonas syringae pv. syringae; Ec, Escherichia coli; Sa, Staphylococcus aureus; Lm, Lysteria monocytogenes; Se, Salmonella enterica. 


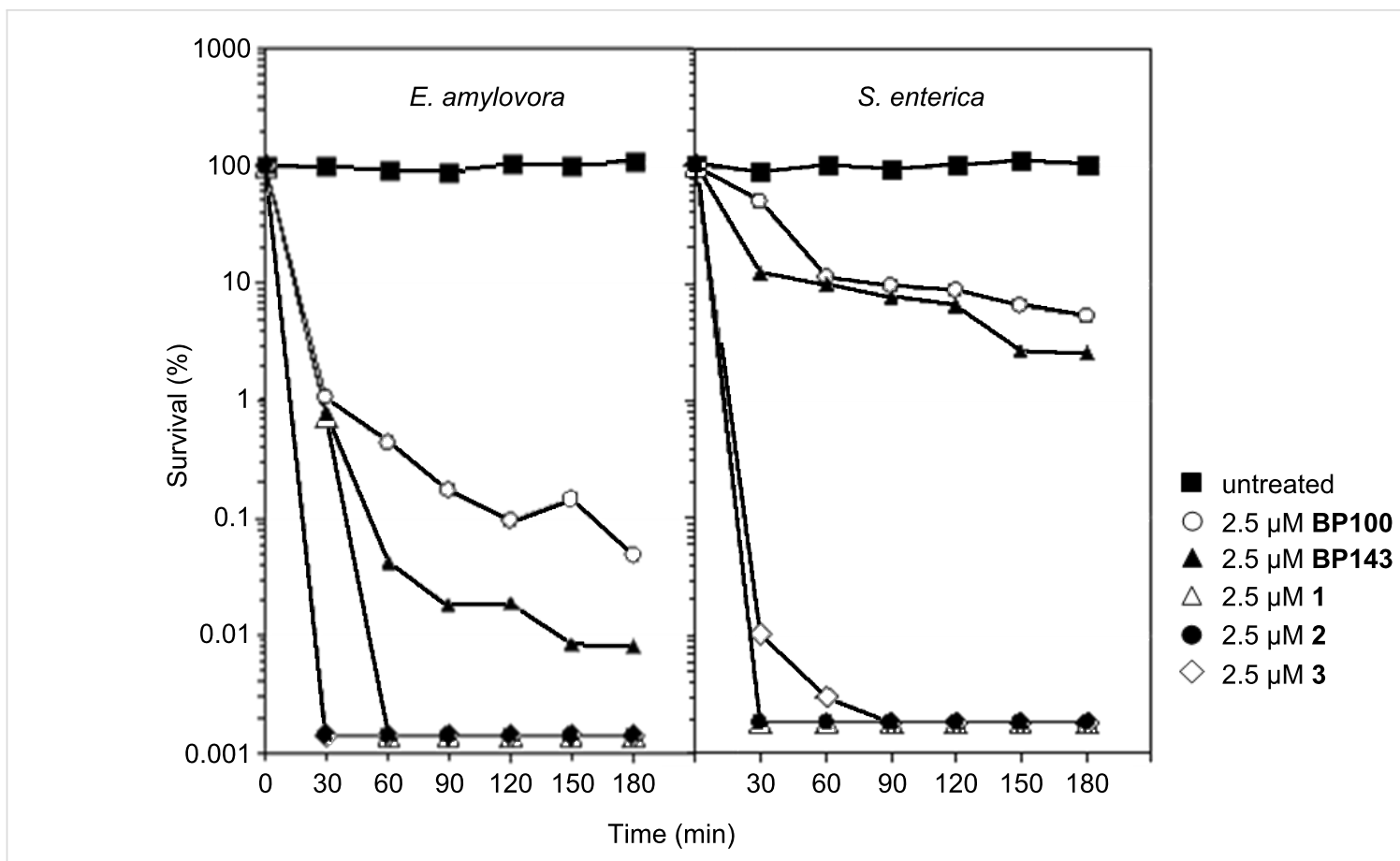

Figure 2: Kinetics of bactericidal activity on E. amylovora and S. enterica in the presence of peptides and carbopeptides. Viable cells were determined at different time intervals.

SDS and in 50\% TFE they became moderately structured, with the degree of secondary structure formation being higher in the latter solvent. In both cases, two local minima near 205 and $220 \mathrm{~nm}$, and a positive band near $195 \mathrm{~nm}$ were observed. In $50 \%$ TFE, we estimated an $\alpha$-helical content of $41 \%$ for carbopeptide 1 and of $19 \%$ for carbopeptide 3. Monomeric undecapeptide BP100 also became moderately structured in $50 \%$ TFE with an $\alpha$-helical content of $21 \%$.

\section{Discussion}

Several studies have demonstrated that covalently tethering a number of peptides to a template can improve overall avidity for targets such as cell membranes [9-15]. In this study we used carbohydrate templates for the design of multivalent antimicrobial peptides targeted to control plant and human pathogenic bacteria and explored whether multivalency enhances the antimicrobial activity. These multivalent constructs were obtained by preassembling the antimicrobial peptides BP100 and BP143 to a cDTE or a Gal $p$ carbohydrate template through oxime formation. They were tested against E. amylovora, $X$. axonopodis pv. vesicatoria, $P$. syringae pv. syringae, E. coli, $S$. aureus, $S$. enterica, and L. monocytogenes.

In agreement with previous studies, we observed that the effectiveness of the designed carbopeptides depended on the bacteria, the peptide, and the structure of the template $[14,15]$ For carbopeptides $\mathbf{1}$ and $\mathbf{2}$ containing two monomeric units we should expect at least a two-fold decrease in the MIC values, and for carbopeptide $\mathbf{3}$, incorporating four peptide sequences, the activity should decrease at least four-fold. Against the phytopathogenic bacteria, carbopeptides $\mathbf{1}$ and $\mathbf{3}$, derived from BP100, displayed a multimeric effect that was lower than expected. In contrast, carbopeptide 2 derived from BP143 containing one D-amino acid did not improve the activity of the parent peptide. Against the human pathogens, we did not observe a significant decrease of the MIC values for any of the three carbopeptides. According to Kallenbach and co-workers, multivalent cationic antimicrobial peptides may display a lower activity than expected due to the potential immobilization of the cationic sequences onto the negatively charged bacterial surfaces, which may impede them to reach the bacterial membrane [15]. Similar observations were described by Shai and co-workers for covalently linked pentameric bundles of cationic antimicrobial peptides [14]. These studies demonstrated that the large volume and the charge of the bundles made their passage through the peptidoglycan or the lipopolysaccharide layers difficult, therefore preventing them from accessing the inner membrane. In contrast, despite the fact that a significant decrease of the MIC values was not observed, the preassembly of multiple copies of BP100 and BP143 did have an important effect on the bactericidal activity. The results showed that the carbopeptides $\mathbf{1}-\mathbf{3}$ were significantly more potent than the corresponding monomers, which is in agreement with previous studies [34,35]. This ability to kill the 
a)

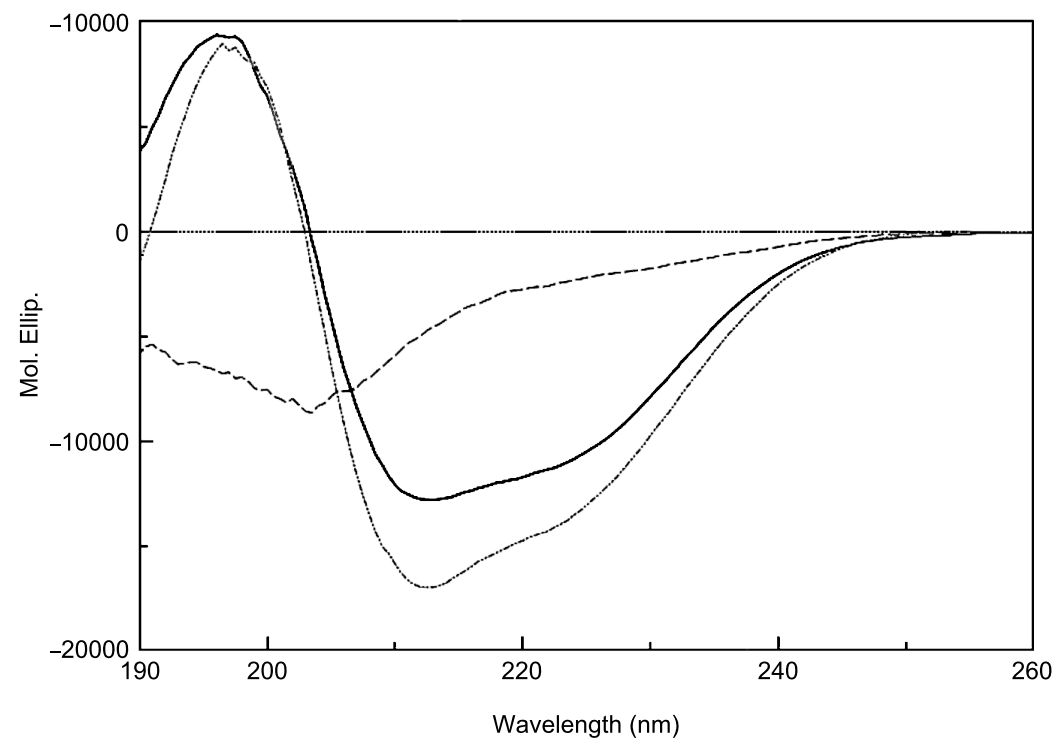

b)

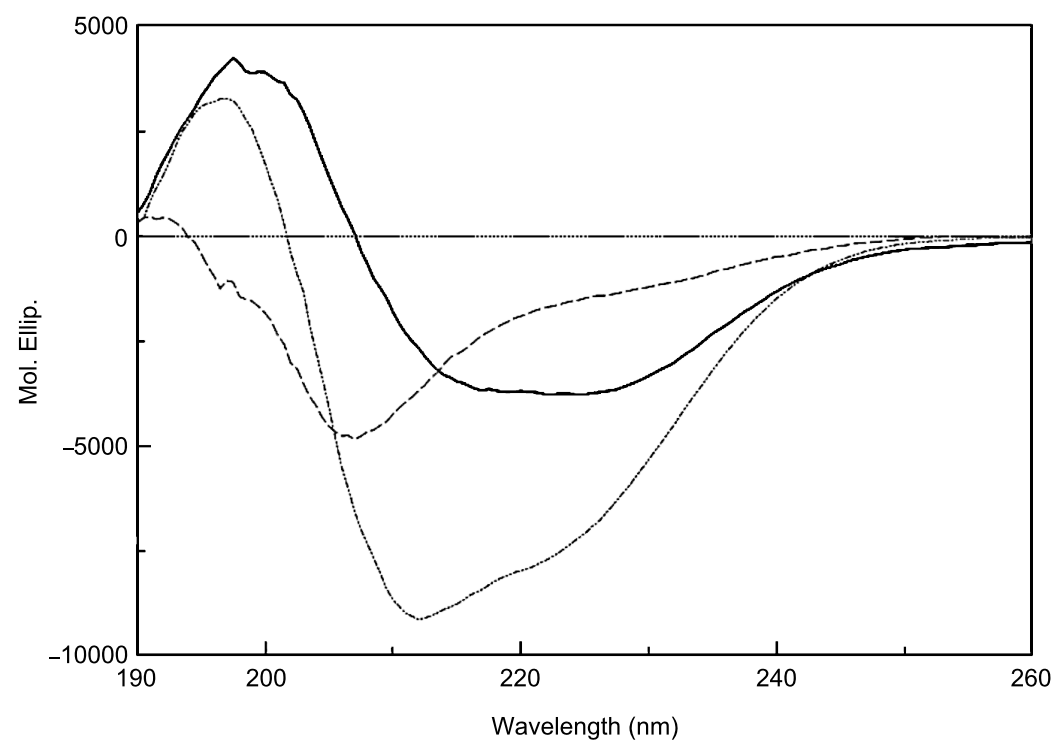

Figure 3: CD spectra of (a) carbopeptide 1 and of (b) carbopeptide 3 in: (i) $10 \mathrm{mM}$ sodium phosphate buffer at pH 7.4 (broken line, - - -); (ii) $10 \mathrm{mM}$ SDS in $10 \mathrm{mM}$ sodium phosphate buffer at pH 7.4 (solid line, - ) , and (iii) $50 \%$ (v/v) trifluoroethanol in $10 \mathrm{mM}$ sodium phosphate buffer at pH 7.4 (broken dotted line, $\cdot \cdot-\cdot-$ ).

bacteria rapidly confers them a greater capacity to control bacterial cell growth, which may be important for their future potential use as bactericidal agents.

Unlike the parent peptides BP100 and BP143, carbopeptides 1-3 exhibited high activity towards erythrocytes. It has been shown that peptide preassembly may favor the formation of a more organized amphipathic peptide structure compared to the monomers, which has been correlated with a higher degree of hemolysis $[14,36]$. BP100 was originally designed based on an ideal $\alpha$-helical Edmunson wheel and showed a moderate degree of secondary-structure formation by $\mathrm{CD}$. As shown by $\mathrm{CD}$ spec- troscopy, the preassembly of BP100 did not result in a more organized structure, especially for carbopeptide 3, which suggests that the high hemolysis observed for carbopeptides cannot be attributed to a higher degree of secondary-structure formation. A likely explanation for the higher hemolytic activity displayed by carbopeptides could be ascribed to their different interaction with zwitterionic membranes compared to peptide monomers, as has been described in previous reports $[14,36]$.

In summary, this study provides an example of carbopeptides with high antimicrobial activity and highlights the importance 
of peptide preassembly for the hemolysis and for the bactericidal activity. The structure of these carbopeptides includes two or four copies of the antimicrobial peptides BP100 or BP143 linked to a cDTE or a Gal $p$ carbohydrate template. Even though these multivalent compounds exhibited low MIC values against plant and human pathogenic bacteria, a significant multimeric effect was not observed. Our results support the notion that preassembly of antimicrobial peptides to multimeric structures prior to contact with the microbial surface does not necessarily lead to a significant improvement of the antimicrobial activity.

\section{Experimental General methods}

The synthesis of $\mathrm{Boc}_{2}-\mathrm{Aoa}-\mathrm{OH}$ was described in an earlier publication from our laboratories [23]. It is now available from Polypeptide Laboratories (NeoMPS, Strassbourg, France). Automated peptide synthesis was carried out on a fully automated Syro II peptide synthesizer (MultiSynTech). Manual peptide synthesis was performed in polypropylene syringes fitted with a polyethylene porous disk. Solvents and soluble reagents were removed by suction. Chemicals were purchased from commercial suppliers Sigma-Aldrich, Fluka, NovaBiochem (Schwalbach, Germany) or Iris Biotech GmbH (Marktredwitz, Germany) and used without further purification. Microwave heating was performed in a Biotage Initiator instrument (Biotage, Uppsala, Sweden).

An acetate buffer ( $0.1 \mathrm{M}, \mathrm{pH} 4.76)$ was prepared by dissolving an equal amount of $\mathrm{NaOAc} \cdot 3 \mathrm{H}_{2} \mathrm{O}(10 \mathrm{mmol})$ and $\mathrm{AcOH}$ $(10 \mathrm{mmol})$ in water $(200 \mathrm{~mL})$ and then adjusting to $\mathrm{pH} 4.76$ with $\mathrm{NaOH}$ (1 M aq). An acetate buffer (0.1 M, pH 4.76) containing aniline $(100 \mathrm{mM})$ was prepared by dissolving aniline $(10 \mathrm{mmol})$ in the previous acetate buffer $(100 \mathrm{~mL})$. A UV spectrophotometer was used to quantify the amount of Fmoc cleaved.

Peptides were analyzed under standard analytical HPLC conditions with a Dionex instrument composed of an UV-vis Dionex UVD170U detector, a P680 Dionex pump, an ASI-100 Dionex automatic injector, and Chromeleon 6.60 software. Detection was performed at $220 \mathrm{~nm}$. Analysis was carried out with a Kromasil $100 \mathrm{C}_{18}(40 \mathrm{~mm} \times 4.6 \mathrm{~mm}, 3.5 \mu \mathrm{m})$ column with a $2-100 \%$ B linear gradient over $7 \mathrm{~min}$ at a flow rate of $1 \mathrm{~mL} / \mathrm{min}$. Solvent A was $0.1 \%$ aq TFA, and solvent B was $0.1 \%$ TFA in $\mathrm{CH}_{3} \mathrm{CN}$.

Peptide aldehydes, carbohydrate templates and carbopeptides were analyzed under standard analytical HPLC conditions with a Dionex UltiMate 3000 with Chromeleon 6.80SP3 software. Detection was performed at $215 \mathrm{~nm}$. Peptide aldehydes and carbohydrate templates were analyzed with a Phenomenex
Gemini $110 \AA \mathrm{C}_{18}(4.6 \times 50 \mathrm{~mm}, 3 \mu \mathrm{m}$ particle size $)$ with a gradient of $5-80 \%$ B over $5 \mathrm{~min}$ and $80-100 \%$ B over $5 \mathrm{~min}$ (buffer A: $0.1 \%$ formic acid in $\mathrm{H}_{2} \mathrm{O}$; buffer $\mathrm{B}: 0.1 \%$ formic acid in $\mathrm{CH}_{3} \mathrm{CN}$ ) at a flow rate of $1 \mathrm{~mL} / \mathrm{min}$. Carbopeptides were analyzed on a $\mathrm{C}_{4}$ Phenomenex Jupiter $300 \AA(4.6 \times 150 \mathrm{~mm}$, $5 \mu \mathrm{m}$ particle size) with a gradient of $5-20 \%$ B over $2 \mathrm{~min}$, $20-40 \%$ B over $8 \mathrm{~min}$ and $40-100 \%$ B over $2 \mathrm{~min}$ at a flow rate of $1 \mathrm{~mL} / \mathrm{min}$.

Preparative RP-HPLC was performed on a similar Dionex UltiMate 3000 system, equipped with a standard thermostatted column compartment (TCC) and with UV detection at $220 \mathrm{~nm}$. Solvents used for RP-HPLC were (A) $\mathrm{H}_{2} \mathrm{O}$ with $0.1 \%$ TFA, (B) $\mathrm{CH}_{3} \mathrm{CN}$ with $0.1 \%$ TFA, (C) $\mathrm{H}_{2} \mathrm{O}$ and (D) $\mathrm{CH}_{3} \mathrm{CN}$. A Phenomenex Gemini-NX $\mathrm{C}_{18} 110 \AA$ column $(100 \times 21.20 \mathrm{~mm}$, $5 \mu \mathrm{m}$ particle size) was used, running at a flow rate of $10.0 \mathrm{~mL} / \mathrm{min}$ at room temperature with gradients from 5-55\% B over $24 \mathrm{~min}$ and $55-100 \% \mathrm{~B}$ over $11 \min (\operatorname{method} \mathrm{A})$ and at $42{ }^{\circ} \mathrm{C}$ with gradients running from $5-50 \% \mathrm{~B}$ over $24 \mathrm{~min}$, $50-95 \%$ B over $11 \mathrm{~min}$ and $95-100 \%$ B over 2 min (method B). A FeF Chemicals $\mathrm{C}_{4} 250 \AA$ column $(20 \times 250 \mathrm{~mm}, 5 \mu \mathrm{m}$ particle size) was used running at a flow rate of $15 \mathrm{~mL} / \mathrm{min}$ at $42{ }^{\circ} \mathrm{C}$ with a linear gradient of $5-95 \%$ B over $28 \mathrm{~min}$ $(\operatorname{method} \mathrm{C})$.

ESIMS analyses were performed on a MSQ Plus Mass Spectrometer (Thermo) or by using an Esquire 6000 ESI ion Trap LC-MS (Bruker Daltonics). High-resolution mass spectrometry (HRMS) was recorded on a Bruker MicroToF-Q MALDI instrument by using a hybrid quadrupole time-of-flight mass spectrometer (University of Zaragoza).

Circular dichroism (CD) measurements were obtained using a Jasco spectropolarimeter (J-810, Easton, MD, USA) at $25^{\circ} \mathrm{C}$. Spectra were obtained in a fused quartz cell with $1 \mathrm{~mm}$ path length over a wavelength range $190-260 \mathrm{~nm}$ at $0.1 \mathrm{~nm}$ intervals, $50 \mathrm{~nm} / \mathrm{min}$ speed, $0.5 \mathrm{~s}$ response time, and $1 \mathrm{~nm}$ bandwidth.

\section{Solid-phase synthesis of peptides BP100 and BP143}

Peptides were synthesized manually by the solid-phase method using standard Fmoc chemistry. Fmoc-Rink-MBHA resin $(0.56 \mathrm{mmol} / \mathrm{g})$ was used as a solid support. Couplings of the corresponding amino acids Fmoc-Leu-OH, Fmoc-Phe-OH, Fmoc-D-Phe-OH, Fmoc-Lys(Boc)-OH, Fmoc-Ile-OH, and Fmoc-Tyr( $t-\mathrm{Bu})-\mathrm{OH}$ (4 equiv) were performed using ethyl cyanoglyoxylate-2-oxime (Oxyma) (4 equiv), $N, N^{\prime}$-diisopropylcarbodiimide (DIPCDI) (4 equiv) in DMF at room temperature for $1 \mathrm{~h}$. The completion of the reactions was monitored by the Kaiser test. Fmoc group removal was achieved with piperidine/ $\operatorname{DMF}(3: 7,1 \times 2 \mathrm{~min}+1 \times 10 \mathrm{~min})$. After each coupling and 
deprotection step, the resin was washed with DMF $(6 \times 1 \mathrm{~min})$ and $\mathrm{CH}_{2} \mathrm{Cl}_{2}(3 \times 1 \mathrm{~min})$ and air-dried. Once the peptide sequence had been completed, the Fmoc group was removed. Acidolytic cleavage was performed by treatment of the resin with TFA $/ \mathrm{H}_{2} \mathrm{O} / \mathrm{TIS}(95: 2.5: 2.5)$ for $2 \mathrm{~h}$ at room temperature. Following concentration in vacuo by evaporation of TFA and trituration with $\mathrm{Et}_{2} \mathrm{O}$, the crude peptide was dissolved in $\mathrm{H}_{2} \mathrm{O}$ / $\mathrm{CH}_{3} \mathrm{CN}$, lyophilized, analyzed by HPLC, and characterized by ESIMS.

\section{Peptide KKLFKKILKYL-NH 2 (BP100)}

HPLC: $t_{\mathrm{R}}=4.07 \mathrm{~min}(90 \%$ purity); $\operatorname{ESIMS}(\mathrm{m} / \mathrm{z}): 1420.87$ $[\mathrm{M}+\mathrm{H}]^{+}$.

Peptide KKLfKKILKYL-NH 2 (BP143)

HPLC: $t_{\mathrm{R}}=6.28 \min (84 \%$ purity); $\operatorname{ESIMS}(\mathrm{m} / \mathrm{z}): 1420.87$ $[\mathrm{M}+\mathrm{H}]^{+}$.

\section{Solid-phase synthesis of peptide aldehydes 4 and 5}

TentaGel S NH $\mathrm{N}_{2}$ (TG) resin $(0.27 \mathrm{mmol} / \mathrm{g})$ was placed in a syringe and swelled with $\mathrm{CH}_{2} \mathrm{Cl}_{2}(3 \times 10 \mathrm{~min})$ and DMF $(3 \times$ $10 \mathrm{~min})$. The ortho backbone amide linker (o-BAL) was incorporated by treating the resin twice with 5-(2-formyl-3,5dimethoxyphenoxy)pentanoic acid (4.0 equiv), $N, N, N^{\prime}, N^{\prime}-$ tetramethyl- $O$-(1H-benzotriazol-1-yl)uronium hexafluorophosphate (HBTU) (3.8 equiv), 1-hydroxybenzotriazole (HOBt) (4.0 equiv), and $N, N$-diisopropylethylamine (DIPEA) (7.8 equiv) in DMF at room temperature for $12 \mathrm{~h}$. Washings were performed with DMF $(3 \times 1 \mathrm{~min}), \mathrm{CH}_{2} \mathrm{Cl}_{2}(3 \times 1 \mathrm{~min})$ and DMF $(3 \times 1 \mathrm{~min})$. Next a reductive amination was performed by using aminoacetaldehyde dimethyl acetal (10 equiv) and $\mathrm{NaBH}_{3} \mathrm{CN}$ (10 equiv) suspended in AcOH/DMF (1:99). This suspension was added to the $o-\mathrm{BAL}-\mathrm{TG}$ resin and the mixture was heated in a microwave instrument at $60{ }^{\circ} \mathrm{C}$ for $10 \mathrm{~min}$. The resin was washed with DMF $(3 \times 1 \mathrm{~min}), \mathrm{CH}_{2} \mathrm{Cl}_{2}(3 \times 1 \mathrm{~min})$ and dichloroethane $(\mathrm{DCE})(3 \times 1 \mathrm{~min})$ and the reductive amination step was repeated. Then, Fmoc-Leu-OH (10 equiv) was dissolved in DCE/DMF (10:1), DIPCDI (5 equiv) was added, and after preactivation for $10 \mathrm{~min}$, the slurry was transferred to the resin. The reaction mixture was heated in a microwave instrument to $60{ }^{\circ} \mathrm{C}$ for $2 \times 10 \mathrm{~min}$, and then the resin was washed with DMF $(3 \times 1 \mathrm{~min}), \mathrm{CH}_{2} \mathrm{Cl}_{2}(3 \times 1 \mathrm{~min})$ and DMF $(3 \times 1 \mathrm{~min})$. Peptide elongation was performed on the fully automatic synthesizer MultiSynTech Syro II by repeated cycles of amino acid coupling, Fmoc group removal and washings. The amino acid couplings were carried out by using the corresponding Fmoc-amino acid (6 equiv), HBTU (5.8 equiv), HOBt (6 equiv) and DIPEA (11.7 equiv) shaking the mixture for $2 \mathrm{~h}$ at room temperature. DMF was used as solvent for all the couplings except for Fmoc-Phe-OH and Fmoc-D-Phe-OH, which were coupled in $N$-methyl-2-pyrrolidinone (NMP). Each coupling step was repeated twice. The Fmoc group was removed by treating the resin with piperidine/DMF $(2: 3,3 \mathrm{~min})$ followed by two treatments of piperidine/DMF $(1: 4,12+$ $15 \mathrm{~min})$. After coupling and deprotection steps the resin was washed with DMF $(3 \times 1 \mathrm{~min}), \mathrm{CH}_{2} \mathrm{Cl}_{2}(1 \times 1 \mathrm{~min})$ and DMF ( $3 \times 1 \mathrm{~min})$. Once the second amino acid was coupled, a Fmoc quantification was performed to estimate the overall loss in loading.

Once the synthesis was completed, peptides were individually cleaved from the resin with TFA/ $\mathrm{H}_{2} \mathrm{O}$ (95:5) for $2 \mathrm{~h}$. Following concentration in vacuo by evaporation of TFA and trituration with $\mathrm{Et}_{2} \mathrm{O}$, the crude peptides were dissolved in $\mathrm{H}_{2} \mathrm{O}$, analyzed by HPLC, purified by preparative RP-HPLC using Method A and characterized by LC-MS.

Peptide aldehyde KKLFKKILKYLG-H (4)

HPLC: $t_{\mathrm{R}}=2.08 \min (99 \%$ purity); $\operatorname{ESIMS}(\mathrm{m} / \mathrm{z}): 366.7$

$[\mathrm{M}+4 \mathrm{H}]^{4+}, 488.6[\mathrm{M}+3 \mathrm{H}]^{3+}$.

Peptide aldehyde KKLfKKILKYLG-H (5)

HPLC: $t_{\mathrm{R}}=2.20 \mathrm{~min}(99 \%$ purity); $\operatorname{ESIMS}(\mathrm{m} / \mathrm{z}): 366.6$ $[\mathrm{M}+4 \mathrm{H}]^{4+}, 488.5[\mathrm{M}+3 \mathrm{H}]^{3+}$.

\section{Preparation of the aminooxy-functionalized templates CDTE and Galp}

The synthesis of the functionalized cyclo-dithioerythritol (cDTE) and $\alpha$-D-galactopyranoside (Gal $p$ ) templates have been described in earlier publications [23,30].

\section{Synthesis of carbopeptide (KKLFKKILKYL- $\left.{ }_{2} \mathrm{H}_{4} \mathrm{~N}\right)_{2^{-}}$ CDTE (1)}

(4R,5S)-1,2-Dithiane-4,5-diyl bis(Boc) $)_{2}$-Aoa (cDTE) (12.7 mg, $18.2 \mu \mathrm{mol})$ was dissolved in TFA/ $\mathrm{CH}_{2} \mathrm{Cl}_{2}(1: 1,2 \mathrm{~mL})$ and stirred for $1 \mathrm{~h}$. The solution was then concentrated in vacuo, redissolved in a small amount of water and lyophilized to afford (4R,5S)-1,2-dithiane-4,5-diyl bis(2-Aoa) as a white powder. This template and the peptide aldehyde $4(65.7 \mathrm{mg}, 45.0 \mu \mathrm{mol})$ were dissolved in $6.2 \mathrm{~mL}$ of a $1: 1$ solution of $\mathrm{CH}_{3} \mathrm{CN}$ and an acetate buffer ( $0.1 \mathrm{M}, \mathrm{pH} 4.76)$ containing aniline (100 mM). The reaction mixture was stirred for $3 \mathrm{~h}$ and purified by preparative RP-HPLC using Method B (24.3 mg, 42\% yield).

HPLC: $t_{\mathrm{R}}=2.50 \min (98 \%$ purity); $\operatorname{ESIMS~}(\mathrm{m} / \mathrm{z}): 1594.5$ $[\mathrm{M}+2 \mathrm{H}]^{2+}, 1063.5[\mathrm{M}+3 \mathrm{H}]^{3+}, 797.8[\mathrm{M}+4 \mathrm{H}]^{4+}, 638.4$ $[\mathrm{M}+5 \mathrm{H}]^{5+}, 532.2[\mathrm{M}+6 \mathrm{H}]^{6+}$; HRMS-MALDI $(\mathrm{m} / \mathrm{z})$ : 
$[\mathrm{M}+\mathrm{Na}]^{+}$calcd for $\mathrm{C}_{156} \mathrm{H}_{264} \mathrm{~N}_{36} \mathrm{NaO}_{30} \mathrm{~S}_{2}, 3208.9753$; found, 3208.9737 .

\section{Synthesis of carbopeptide (KKLfKKILKYL- $\left.\mathrm{C}_{2} \mathrm{H}_{4} \mathrm{~N}\right)_{2}-$ cDTE (2)}

$(4 R, 5 S)$-1,2-Dithiane-4,5-diyl bis(2-(Boc $)_{2}$-Aoa) (cDTE) $(4.8 \mathrm{mg}, 6.9 \mu \mathrm{mol})$ was dissolved in TFA $/ \mathrm{CH}_{2} \mathrm{Cl}_{2}(1: 1,1 \mathrm{~mL})$ and stirred for $1 \mathrm{~h}$. The solution was then concentrated in vacuo, redissolved in a small amount of water and lyophilized to afford $(4 R, 5 S)$-1,2-dithiane-4,5-diyl bis(2-Aoa) as a white powder. This template and the peptide aldehyde $5(30.2 \mathrm{mg}, 20.6 \mu \mathrm{mol})$ were dissolved in 1:1 solution $(2 \mathrm{~mL})$ of $\mathrm{CH}_{3} \mathrm{CN}$ and an acetate buffer $(0.1 \mathrm{M}, \mathrm{pH} 4.76)$ containing aniline $(100 \mathrm{mM})$. The reaction mixture was stirred for $3 \mathrm{~h}$ and purified by preparative RP-HPLC using Method B (13.6 mg, 62\% yield).

HPLC: $t_{\mathrm{R}}=2.51 \mathrm{~min}(98 \%$ purity); $\operatorname{ESIMS}(\mathrm{m} / \mathrm{z}): 1594.1$ $[\mathrm{M}+2 \mathrm{H}]^{2+}, 1063.5[\mathrm{M}+3 \mathrm{H}]^{3+}, 797.9[\mathrm{M}+4 \mathrm{H}]^{4+}, 638.4$ $[\mathrm{M}+5 \mathrm{H}]^{5+}, 532.2[\mathrm{M}+6 \mathrm{H}]^{6+}$; HRMS-MALDI $(\mathrm{m} / \mathrm{z})$ $[\mathrm{M}+\mathrm{H}]^{+}$calcd for $\mathrm{C}_{156} \mathrm{H}_{265} \mathrm{~N}_{36} \mathrm{O}_{30} \mathrm{~S}_{2}, 3186.9753$; found, 3186.9820 .

\section{Synthesis of carbopeptide (KKLFKKILKYL- $\left.{ }_{2} \mathrm{H}_{4} \mathrm{~N}\right)_{4-}$ Galp (3)}

Methyl 2,3,4,6-tetra- $O$-((Boc) $)_{2}$-Aoa)- $\alpha$-D-Galp (3.4 mg, $2.6 \mu \mathrm{mol})$ was dissolved in TFA/ $\mathrm{CH}_{2} \mathrm{Cl}_{2}(1: 1,0.5 \mathrm{~mL})$ and stirred for $30 \mathrm{~min}$ at room temperature. The solution was then concentrated to dryness, redissolved in a small amount of water and lyophilized to afford methyl 2,3,4,6-tetra- $O$-Aoa- $\alpha$-D-Gal $p$ as a white powder. This lyophilized template was dissolved in $1.2 \mathrm{~mL}$ of a $1: 1$ solution of $\mathrm{CH}_{3} \mathrm{CN}$ and an acetate buffer (0.1 M, pH 4.76). Peptide aldehyde 4 (19.3 mg, $13.2 \mu \mathrm{mol})$ was added, and the mixture was stirred at room temperature. The reaction was followed by HPLC. After $4 \mathrm{~h}$, an additional amount of peptide aldehyde $4(20 \mathrm{mg}, 13.7 \mu \mathrm{mol})$ dissolved in $1.1 \mathrm{~mL}$ of a $1: 1$ solution of $\mathrm{CH}_{3} \mathrm{CN}$ and an acetate buffer $(0.1 \mathrm{M}, \mathrm{pH} 4.76)$ containing aniline $(100 \mathrm{mM})$ was added. After further $2.5 \mathrm{~h}$, the reaction was completed. The reaction mixture was purified by RP-HPLC using Method C (10.7 mg, 64\% yield).

HPLC: $t_{\mathrm{R}}=6.23 \mathrm{~min}(90 \%$ purity); ESIMS $\mathrm{m} / \mathrm{z}: 1566.3$ $[\mathrm{M}+4 \mathrm{H}]^{4+}, 1253.8[\mathrm{M}+5 \mathrm{H}]^{5+}, 1045.1[\mathrm{M}+6 \mathrm{H}]^{6+}, 895.7$ $[\mathrm{M}+7 \mathrm{H}]^{7+}, 784.2[\mathrm{M}+8 \mathrm{H}]^{8+}, 697.2[\mathrm{M}+9 \mathrm{H}]^{9+}, 627.5$ $[\mathrm{M}+10 \mathrm{H}]^{10+}\left([\mathrm{M}]^{+}\right.$calcd for $\left.\mathrm{C}_{311} \mathrm{H}_{526} \mathrm{~N}_{72} \mathrm{O}_{62}, 6262.022 \mathrm{Da}\right)$.

\section{Bacterial strains and growth conditions}

As described in [28], the following plant pathogenic and foodborne bacterial strains were used: Erwinia amylovora PMV6076 (Institut National de la Recherche Agronomique, Angers, France), Pseudomonas syringae pv. syringae EPS94
(Institut de Tecnologia Agroalimentària, Universitat de Girona, Spain), and Xanthomonas axonopodis pv. vesicatoria 2133-2 (Instituto Valenciano de Investigaciones Agrarias, Valencia, Spain). Moreover, the following bacterial strains were also used: Escherichia coli ATCC NCTC 5934, Listeria monocytogenes ATCC 15313, Staphylococcus aureus subsp. aureus ATCC 9144 and Salmonella enterica subsp. enterica LT2 ATCC 15277.

All bacteria were stored in Luria Bertani (LB) broth except for L. monocytogenes, which was stored in Brain Heart Infusion (BHI) broth (Oxoid, Hampshire, United Kingdom) supplemented with glycerol $(20 \%)$ and maintained at $-80{ }^{\circ} \mathrm{C}$. E. amylovora and $P$. syringae pv. syringae were scrapped from LB agar after growing for $24 \mathrm{~h}$ at $25^{\circ} \mathrm{C} ; X$. axonopodis pv. vesicatoria was scrapped from LB agar after growing for $48 \mathrm{~h}$ at $25^{\circ} \mathrm{C}$; S. aureus, E. coli and S. enterica were scrapped from $\mathrm{LB}$ agar after growing for $24 \mathrm{~h}$ at $37^{\circ} \mathrm{C} ;$ L. monocytogenes was scrapped from BHI agar after growing for $24 \mathrm{~h}$ at $37^{\circ} \mathrm{C}$. The cell material was suspended in sterile water to obtain a suspension of $10^{8} \mathrm{CFU} \mathrm{mL}{ }^{-1}$.

\section{Antibacterial activity}

As described in [28], lyophilized compounds were solubilized in sterile Milli-Q water to a final concentration of $1000 \mu \mathrm{M}$ and filter sterilized through a $0.22 \mu \mathrm{m}$ pore filter. For minimum inhibitory concentration (MIC) assessment, dilutions of the compounds were made to obtain a final concentration of 200 , $100,75,50,25,12.5$ and $6 \mu \mathrm{M}$. Twenty microliters of each dilution were mixed in a microtiter plate well with $20 \mu \mathrm{L}$ of the corresponding suspension of the bacterial indicator, $160 \mu \mathrm{L}$ of Trypticase Soy Broth (TSB) (BioMèrieux, France) for E. amylovora, P. syringae pv. syringae, X. axonopodis pv. vesicatoria, S. aureus, E. coli and S. enterica or BHI for L. monocytogenes to a total volume of $200 \mu \mathrm{L}$. Three replicates for each strain, compound and concentration were used. Positive controls contained water instead of compound, and negative controls contained compounds without bacterial suspension. Microbial growth was automatically determined by optical density measurement at $600 \mathrm{~nm}$ (Bioscreen C, Labsystem, Helsinki, Finland). Microplates were incubated at $25{ }^{\circ} \mathrm{C}$ for plant pathogenic bacteria and at $37{ }^{\circ} \mathrm{C}$ for foodborne bacterial strains, with $20 \mathrm{~s}$ shaking before hourly absorbance measurement, for $48 \mathrm{~h}$. The experiment was repeated twice. The MIC was taken as the lowest compound concentration with no growth at the end of the experiment.

\section{Bactericidal activity}

The bactericidal activity was determined for peptides BP100 and BP143 and for carbopeptides 1-3 by using E. amylovora and $S$. enterica as indicators of plant pathogenic and foodborne 
bacteria. Ringer bacterial suspensions at $1-1.5 \times 10^{6} \mathrm{CFU} \mathrm{mL}^{-1}$ were incubated in a $2.5 \mu \mathrm{M}$ concentration of the corresponding compound, including also a negative control containing only Ringer solution. A total volume of $13 \mathrm{~mL}$ suspension was incubated for $3 \mathrm{~h}$ at room temperature. Aliquots of $1.5 \mathrm{~mL}$ were removed at $30 \mathrm{~min}$ intervals, tenfold-diluted if necessary, and spread in triplicate onto LB agar plates by using a spiral plater (Eddy Jet; IUL Instruments, Spain). After $24 \mathrm{~h}$ of incubation at $25^{\circ} \mathrm{C}$ for E. amylovora, and $37^{\circ} \mathrm{C}$ for $S$. enterica, the concentrations of the suspensions were obtained with an automatic counter (Flash and Go; IUL Instruments, Spain) by incorporating the software Counter Mat version 5.0. Values are expressed as percentages of survival from the start of the experiment.

\section{Hemolytic activity}

As described in [28], the hemolytic activity of the compounds was evaluated by determining hemoglobin release from erythrocyte suspensions of fresh human blood $(5 \% \mathrm{vol} / \mathrm{vol})$. Blood was aseptically collected using a BD vacutainer K2E System with EDTA (Belliver Industrial State, Plymouth, U.K.) and stored for less than $2 \mathrm{~h}$ at $4{ }^{\circ} \mathrm{C}$. Blood was centrifuged at $6000 \mathrm{~g}$ for $5 \mathrm{~min}$, washed three times with tris(hydroxymethyl)aminomethane (TRIS) buffer (10 mM TRIS, $150 \mathrm{mM} \mathrm{NaCl}, \mathrm{pH}$ 7.2) and diluted. Compounds were solubilized in TRIS buffer to a final concentration of 500, 300 and $100 \mu \mathrm{M}$. Fifty microliters of human red blood cells were mixed with $50 \mu \mathrm{L}$ of the compound solution and incubated under continuous shaking for $1 \mathrm{~h}$ at $37^{\circ} \mathrm{C}$. Then, the tubes were centrifuged at $3500 \mathrm{~g}$ for $10 \mathrm{~min}$. Eighty microliter aliquots of the supernatant were transferred to 100-well microplates (Bioscreen) and diluted with $80 \mu \mathrm{L}$ of Milli-Q water. Hemolysis was measured as the absorbance at $540 \mathrm{~nm}$ with a Bioscreen plate reader. Complete hemolysis was determined in TRIS buffer plus melittin at $100 \mu \mathrm{M}$ (Sigma-Aldrich, Madrid, Spain) as a positive control. The percentage of hemolysis $(H)$ was calculated by using the following equation: $H=100 \times\left[\left(O_{\mathrm{p}}-O_{\mathrm{b}}\right) /\left(O_{\mathrm{m}}-O_{\mathrm{b}}\right)\right]$, where $O_{\mathrm{p}}$ was the density for a given compound concentration, $O_{\mathrm{b}}$ for the buffer, and $O_{\mathrm{m}}$ for the melittin positive control.

\section{Circular dichroism spectroscopy}

Carbopeptides were dissolved to $100 \mu \mathrm{M}$ concentration in $10 \mathrm{mM}$ sodium phosphate buffer at $\mathrm{pH} 7.4$, in $50 \%(\mathrm{v} / \mathrm{v})$ TFE in $10 \mathrm{mM}$ sodium phosphate buffer at $\mathrm{pH} 7.4$, and in $10 \mathrm{mM}$ SDS in $10 \mathrm{mM}$ sodium phosphate buffer at $\mathrm{pH}$ 7.4. A baseline correction was made with only solvent in the cell. Data were expressed in terms of mean residue ellipticity $[\theta]\left(\mathrm{deg} \mathrm{cm}^{2}\right.$ $\mathrm{dmol}^{-1}$ ), calculated per mol of total amide groups present in the different peptides. The percentage helicity of the peptide was calculated as follows: $\alpha$-helix $(\%)=\left([\theta]_{222}-[\theta]_{222}^{0}\right) /[\theta]_{222}^{100}$, where $[\theta]_{222}$ is the experimentally observed absolute mean residue ellipticity at $222 \mathrm{~nm}$. Values for $[\theta]_{222}^{0}$ and $[\theta]_{222}^{100}$, corresponding to 0 and $100 \%$ helix content at $222 \mathrm{~nm}$,

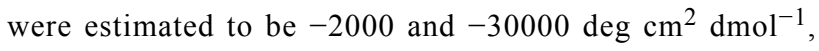
respectively [37].

\section{Supporting Information}

\section{Supporting Information File 1}

HPLC, ESIMS of peptide aldehydes 4 and $\mathbf{5}$. HPLC,

ESIMS, and HRMS of carbopeptides 1-3.

[http://www.beilstein-journals.org/bjoc/content/

supplementary/1860-5397-8-237-S1.pdf]

\section{Acknowledgements}

Imma Güell is recipient of a predoctoral fellowship from the Generalitat de Catalunya. This work was supported by grants AGL2006-13564/AGR and AGL2009-13255-C02-02/AGR from MICINN of Spain.

\section{References}

1. Brogden, K. A. Nat. Rev. Microbiol. 2005, 3, 238-250. doi:10.1038/nrmicro1098

2. Yeaman, M. R.; Yount, N. Y. Pharmacol. Rev. 2003, 55, 27-55. doi:10.1124/pr.55.1.2

3. Jenssen, H.; Hamill, P.; Hancock, R. E. W. Clin. Microbiol. Rev. 2006, 19, 491-511. doi:10.1128/CMR.00056-05

4. Zhang, L.; Falla, T. J. Expert Opin. Pharmacother. 2006, 7, 653-663. doi:10.1517/14656566.7.6.653

5. Bechinger, B.; Lohner, K. Biochim. Biophys. Acta 2006, 1758, 1529-1539. doi:10.1016/j.bbamem.2006.07.001

6. Hancock, R. E. W.; Sahl, H.-G. Nat. Biotechnol. 2006, 24, 1551-1557. doi:10.1038/nbt1267

7. Huang, H. W. Biochim. Biophys. Acta 2006, 1758, 1292-1302. doi:10.1016/j.bbamem.2006.02.001

8. Marcos, J. F.; Gandía, M. Expert Opin. Drug Discovery 2009, 4, 659-671. doi:10.1517/17460440902992888

9. Giuliani, A.; Rinaldi, A. C. Cell. Mol. Life Sci. 2011, 68, 2255-2266. doi:10.1007/s00018-011-0717-3

10. Liu, S. P.; Zhou, L.; Lakshminarayanan, R.; Beuerman, R. W. Int. J. Pept. Res. Ther. 2010, 16, 199-213. doi:10.1007/s10989-010-9230-z

11. Liu, Z.; Young, A. W.; Hu, P.; Rice, A. J.; Zhou, C.; Zhang, Y.; Kallenbach, N. R. ChemBioChem 2007, 8, 2063-2065. doi:10.1002/cbic.200700502

12. Pawlak, M.; Meseth, U.; Vogel, H.; Dhanapal, B.; Mutter, M. Protein Sci. 1994, 3, 1788-1805. doi:10.1002/pro.5560031019

13. Pieters, R. J.; Arnusch, C. J.; Breukink, E. Protein Pept. Lett. 2009, 16, 736-742.

14. Sal-Man, N.; Oren, Z.; Shai, Y. Biochemistry 2002, 41, 11921-11930. doi:10.1021/bi0260482

15. Young, A. W.; Liu, Z.; Zhou, C.; Totsingan, F.; Jiwrajka, N.; Shi, Z.; Kallenbach, N. R. Med. Chem. Commun. 2011, 2, 308-314. doi:10.1039/c0md00247j

16. Leitgeb, B.; Szekeres, A.; Manczinger, L.; Vágvölgyi, C.; Kredics, L. Chem. Biodiversity 2007, 4, 1027-1051. doi:10.1002/cbdv.200790095 
17. Rozgonyi, F.; Szabo, D.; Kocsis, B.; Ostorhazi, E.; Abbadessa, G.; Cassone, M.; Wade, J. D.; Otvos, L., Jr. Curr. Med. Chem. 2009, 16, 3996-4002.

18. Haas, D. H.; Murphy, R. M. J. Pept. Res. 2004, 63, 451-459. doi:10.1111/j.1399-3011.2004.00149.x

19. Li, H.; Wang, L.-X. Org. Biomol. Chem. 2003, 1, 3507-3513. doi:10.1039/b307995c

20. Röglin, L.; Lempens, E. H. M.; Meijer, E. W. Angew. Chem., Int. Ed. 2011, 50, 102-112. doi:10.1002/anie.201003968

21. Sebestik, J.; Niederhafner, P.; Jezek, J. Amino Acids 2011, 40, 301-370. doi:10.1007/s00726-010-0707-z

22. Tuchscherer, G.; Mutter, M. J. Biotechnol. 1995, 41, 197-210. doi:10.1016/0168-1656(95)00010-N

23. Brask, J.; Jensen, K. J. J. Pept. Sci. 2000, 6, 290-299. doi:10.1002/1099-1387(200006)6:6<290::AID-PSC257>3.0.CO;2-L

24. Jensen, K. J.; Brask, J. Cell. Mol. Life Sci. 2002, 59, 859-869. doi:10.1007/s00018-002-8473-z

25. Jensen, K. J.; Brask, J. Biopolymers 2005, 80, 747-761. doi:10.1002/bip.20300

26. Brask, J.; Jensen, K. J. Bioorg. Med. Chem. Lett. 2001, 11, 697-700. doi:10.1016/S0960-894X(01)00035-X

27. Tofteng, A. P.; Hansen, T. H.; Brask, J.; Nielsen, J.; Thulstrup, P. W.; Jensen, K. J. Org. Biomol. Chem. 2007, 5, 2225-2233. doi:10.1039/b704159d

28. Badosa, E.; Ferre, R.; Planas, M.; Feliu, L.; Besalú, E.; Cabrefiga, J.; Bardají, E.; Montesinos, E. Peptides 2007, 28, 2276-2285. doi:10.1016/j.peptides.2007.09.010

29. Güell, I.; Cabrefiga, J.; Badosa, E.; Ferre, R.; Talleda, M.; Bardají, E.; Planas, M.; Feliu, L.; Montesinos, E. Appl. Environ. Microbiol. 2011, 77 2667-2675. doi:10.1128/AEM.02759-10

30. Høiberg-Nielsen, R.; Tofteng Shelton, A. P.; Sørensen, K. K.; Roessle, M.; Svergun, D. I.; Thulstrup, P. W.; Jensen, K. J.; Arleth, L. ChemBioChem 2008, 9, 2663-2672. doi:10.1002/cbic.200800263

31. Dirksen, A.; Dirksen, S.; Hackeng, T. M.; Dawson, P. E. J. Am. Chem. Soc. 2006, 128, 15602-15603. doi:10.1021/ja067189k

32. Dirksen, A.; Hackeng, T. M.; Dawson, P. E. Angew. Chem., Int. Ed. 2006, 45, 7581-7584. doi:10.1002/anie.200602877

33. Thygesen, M. B.; Munch, H.; Sauer, J.; Cló, E.; Jørgensen, M. R.; Hindsgaul, O.; Jensen, K. J. J. Org. Chem. 2010, 75, 1752-1755. doi:10.1021/jo902425v

34. Lorenzón, E. N.; Cespedes, G. F.; Vicente, E. F.; Nogueira, L. G.; Bauab, T. M.; Castro, M. S.; Cilli, E. M. Antimicrob. Agents Chemother. 2012, 56, 3004-3010. doi:10.1128/AAC.06262-11

35. Lee, J. Y.; Yang, S.-T.; Lee, S. K.; Jung, H. H.; Shin, S. Y.; Hahm, K.-S.; Kim, J. Y. FEBS J. 2008, 275, 3911-3920. doi:10.1111/j.1742-4658.2008.06536.x

36. Arnusch, C. J.; Branderhorst, H.; de Kruijff, B.; Liskamp, R. M. J.; Breukink, E.; Pieters, R. J. Biochemistry 2007, 46, 13437-13442. doi:10.1021/bi7015553

37. Lee, D. G.; Park, Y.; Jin, I.; Hahm, K.-S.; Lee, H.-H.; Moon, Y.-H.; Woo, E.-R. J. Pept. Sci. 2004, 10, 298-303. doi:10.1002/psc.504

\section{License and Terms}

This is an Open Access article under the terms of the Creative Commons Attribution License

(http://creativecommons.org/licenses/by/2.0), which permits unrestricted use, distribution, and reproduction in any medium, provided the original work is properly cited.

The license is subject to the Beilstein Journal of Organic Chemistry terms and conditions:

(http://www.beilstein-journals.org/bjoc)

The definitive version of this article is the electronic one which can be found at:

doi:10.3762/bjoc. 8.237 